\title{
GOVERNMENT STRUCTURE, SPATIAL ADMINISTRATIVE REFORMS AND NATIONAL DEVELOPMENT
}

\author{
UKWU I. UKWU \\ University of Nigeria \\ Enugu Campus
}

The spatial dimension of Governmental structure has to do with the number and status of significant geo-political units, their levels and spheres of authority, and how the entire system works. On the evidence of the state of the nation today the Nigerian system has not worked very well. The question is why? This paper attempts to offer some answers by examining the evolution and significance of Nigeria's geo-political structure.

\section{The Evolution of Geopolitical Structure}

The traditional political systems in Nigeria range in type over "a gradient of centralization" (Horton 1971) from small-scale uncentralized lineage systems to largescale centralized territorial empires. Small-scale uncentralized polities occupied the southeastern gradient, from the Jos Plateau to the coast and from the Lower-Niger valley to the eastern borderlands, an area accounting for about a third of Nigeria's present population. Independent city states, evolved during centuries of European trade, were concentrated on the coast, the Cross River, the Niger Delta, the Lower Niger and NigerBenue confluence. The bulk of the country was occupied by kingdoms and empires of varying sizes, culminating in the imperial Caliphate of Sokoto, to which the travails of a complex confederal system were all-too-familiar.

The establishment of British colonial rule led to supersession of the sovereignty of the various traditional polities and the progressive transformation of geopolitical units and relationships to fit the new system.

Colonial control was established from three separate bases under different auspices: from Calabar, under the Foreign Office Consular Administration; from Lagos, under the Colonial Office, by direct military intervention and from the Lower and Middle Niger, under the British Merchant adventurers of what was to become the Royal Niger Company (Nicolson 1969). Different administrations were established for the different expanding territories and it was not until 1914, after a number of intermediate rearrangements, that all the territories»were amalgamated into one country, namely the Colony and Protectorate of Nigeria. 
Until 1947 the Government structure was a curious mixture of centralization and devolution, with a dual bureaucratic structure consisting of separate political and departmental administrations only tenuously co-ordinated at the centre. The departmental administration covered the very limited developmental role of the colonial administration, and was organised along functional lines, with technical and professional departments responsible for agriculture, health, public works, marine ports, railways; coal, etc. (Ukwu 1985a).

Under varieties of indirect rule political administration was effected through a hierarchy of levels -- Groups of Provinces and/Divisions, manned by High Commissioner/Lieutenant Governor, Resident and District Officer exercising wideranging judicial and executive powers. But the heart of the system was the Native Authority to which the colonial administration abandoned "all responsibilities for the social and economic well-being of all the peoples of the areas under their control" (Perham 1937). The role of the political officers was restricted to advice and supervision at the Native Authority level. No attempt was made to create political institutions, aimed at bringing the peoples and communities together. Rather, differences in culture and traditions, interests and attitudes, were assiduously cultivated and used to legitimise Pax Britannia.

Only in the twilight of colonial rule in $\wedge 1947$, was a central legislature for all Nigerians established ( Okafor 1981). This development, ironically, was but a prelude to regionalisation, with Nigerian entering Independence as a federation of three regions North, West and East. ${ }^{1}$ The stresses, tensions and conflicts generated within the system quickly led to instability and collapse. A military coup intervened, followed by a civil war.

By the creation of 12 states in 1967.increasedto 19 in 1979, the military addressed two major problems of the structure - the gross imbalance in size among the regions and the frustration of the minorities under the hegemony of the geo-ethnic groups controlling the major regions. At the same time, the monolithic command style of the military regime eroded - the autonomy of the states, reducing them to mere administrative echelons of the central authority. Events during the civilian interregnum of the Second Republic (19791983) revealed that the demand for more states has become even more pressing in some areas, but for new and complex reasons of political arithmetic (Ukwu 1985b). The constitutional formula for power sharing was shown to be unworkable, not least because the necessary lubricant of a cooperative political culture was lacking.

\section{Federal-State Financial Relationships}

Federal-State financial relationships are critical to the functioning of a federal system of government. They are particularly important for the

1 The creation of a fourth region, the Midwestern region in 1964 must be seen in the context of the Political manouvering among the three power blocs. 
prospects of coordinated and even development. As Birch put sat, the financial provisions in a federal constitution will go a long way to determine "the means by which the governments may attempt to maintain economic stability, the rates at which public services are developed in various regions of the country and the extent to which the rates of economic growth will vary between regions" (Birch 1970).

This issue has been very problematic in Nigeria, where the nation's public finance has passed through a quick succession of phases marked by changes in financial relationships between the centre and the regions/ states. Before amalgamation in 1914, the various territories were fiscally independent of one"1 another. Although customs duties were then centralised, separate estimates of revenue and expenditure were kept for each administration until 1926-27 when they were consolidated, only to be separated again when regional governments were introduced in 1948. Since then, in the determined but frustrated search for a fair, equitable and efficient formula for regulating financial relationships among the units, there have been no less than nine revenue allocation review panels, reports and reforms.

The main trends are summarised in Table 1. From the introduction of the federal system to the eve of independence there was progressive increase in regional fiscal autonomy, the principle of derivation gaining in importance as a factor in revenue allocation, attaining its most rigorous application following the Chick Commission Report of 1955. This development emphasised regional differences in resources and income, which, compounded by differing regional perceptions of developmental priorities, led to widening disparities in levels and trends of development.

As independence drew near it became clearer that the divergences were not conducive to even development and national unity. On the eve of Independence the ' Traisman-Tiress report led to an attenuation of the derivation principle through the introduction of a distributable pool account for the regions, which was operated on the principles of "need" and national interest (Philips 1971). With the advent of military rule there began a trend towards fiscal centralism. The states progressively lost many of their powers to raise independent revenue while the criteria for disbursement of funds to states were frequently, pragmatically and unilaterally varied. Non-statutory \{transfers-project grants, subsidies, loans-soon constituted a significant proportion of state revenue. However, there was no abandonment of the formal principle of derivation until the Aboyade Report of $1978^{2}$. Thus the major oil-producing states were in a specially strong fiscal position throughout the first phase of the oil boom, from 1973 to 1978. They became the "Cinderallas" of post-civil war Nigeria.

The Aboyade Report introduced the revolutionary principle of a f ked proportional shareout of Federation Account revenue among the three tiers

2. The 1969 Dina report which de-emphasized the derivation principle was rejected by government (Okigbo etal 1980). 
TABLE 1

\section{CHANGES IN FEDERAL REVENUE ALLOCATION FORMULAE 1948-1980}

$\begin{array}{ll}\begin{array}{l}\text { Fiscal Year of } \\ \text { Commission }\end{array} & \begin{array}{l}\text { Main Allocation } \\ \text { Principle's Cited }\end{array} \\ \begin{array}{l}\text { 1948/49 } \\ \text { Phillipson }\end{array} & \begin{array}{l}\text { Derivation Even } \\ \text { Progress }\end{array} \\ 1953 / 53 & \text { Derivation } \\ \text { Hicks } & \text { Needs } \\ \text { Phillipson } & \text { National/Interest } \\ & \\ 1954 / 55 & \text { Derivation } \\ \text { Chick } & \text { Fiscal Autonomy } \\ \text { 1959/60 } & \text { Derivation Fiscal } \\ \text { Raisman/ } & \text { Autonomy Unified } \\ \text { Trees } & \text { National Policy. }\end{array}$

$1966 / 67$

Binns

$1968 / 69$

Interim

1968/69

Dinner

$1978 / 79$

Aboyade

1980

Okigbo

Deemphasized
Population Equality Social development Internal Revenue Effort
Basic Features of Formulate

Balance after meeting Central Government Budget needs allocated to Regions

Proportions of specified duties and taxes shared among regions by derivation special grants, e.g. capitation, education, police, equalization.

Proportions of specified revenue shared among regions by derivation.

Proportion of specified Revenue shared among Nigerian by derivation creation of Distributable Pool Account with fixed proportional share for each region.

Composition of Distributable Pool and Proportional shares of Regions altered.

Distributable; Pool reallocated to reflect 12 state structure. But Northern States share Northern block allocation on basis of equality of states.

Special Grants Reintroduced but rejected by Government

Minimum Responsibility

Derivation dethroned minimum Fixed Proportion of Federation Account Access Minimum Standards Absorptive Capacity

Revenue Allocated to Federal, State and Local Governments. Individual shares of States and Local Governments in State on basis of defined principles.

As above. But new criteria alter Inter-unit distribution among states and local governments.

Source Adapted from Ukwu I Ukwu "Financing Even Development" in E. J. Nwosu Even Development in Nigeria: Problems and Prospects. Enugu Fourth Dimension 1985, p. 346. 
of government-Federal, State and Local. Although the criteria that were proposed for the relative shares of the individual units at state and local government levels were rejected by the Federal Military Government as "too complicated", the same general procedure was followed by the Okigbo Commission whose "more practical' allocation criteria proved acceptable.

Following the recommendations of the OMgbo Commission and in accordance with the 1979 Constitution, the provisions of the subsisting Revenue Allocation Act have fundamentally altered the fiscal relationship between the Federal Government and the Slate Governments. The new relationship is rather rigidly based on the disbursement of statutory allocations from the Federation Account Neither federal politicians of the Second Republic nor the Military regimes after them have shown any marked inclination to use the permissive clauses in the existing laws to provide for non-statutory transfers in aid of specific objectives. Yet non-statutory grants play an essential role in any federal system. They not only enlarge the overall financial resources of the states, making states more capable of meeting their general responsibilities, but influencing the patterns of state expenditure in favour of aided projects, help to ensure that specific national targets are met (Hardy 1976).

The salutary impact of well-directed federal project grants is very vividly illustrated by the case of the Universal Primary Education Scheme (UPE) introduced by the military regime in 1976 (See Table 2). In the year before the take-off of the scene, the five states with the highest primary school enrolments were all from the Southern StatesImo, Anambra, Bendel, Cross River and Oyo. Together they accounted for 53.3\% of school enrolment although their estimated share of the national population was only $32.7 \%$. At the other end the states with the lowest enrolments - Niger, Bauchi, Sokoto, Borno and Plateau - were all northern states. Together they accounted for $10.1 \%$ of school enrolments as against $23.6 \%$ of estimated populations.

From 1976 to 1979,' the Federal Military Government made recurrent grants of $\mathrm{N1}, 892$ million and capital grants of N826 million to states in support of the UPE scheme. At the end of the exercise the picture had been transformed The most spectacular changes had. been registered in the hitherto "disadvantaged" states. In 1980 the group of 5 leading states Oyo, Imo, Kano, Kaduna and Anambra -included two northern states. Furthermore, the group share of $41.2 \%$ of school enrolment was quite close to its $39.9 \%$ share of estimated population. At the other end the five states with the least enrolment - Ogun, Borno, Bauchi, Niger and Rivers -- included two southern states. Again, their aggregate $14.9 \%$ of school enrolment was not too far from their $17.8 \%$ share of the estimated populations. At primary level, then, the educational gap had been substantially bridged by four years of purposive federal-state cooperative action. 
TABLE 2

\section{FEDERAL GRANTS AND THE REDUCTION OF INTER-STATE INEQUALITY IN PRIMARY EDUCATION 1975 - 1980}

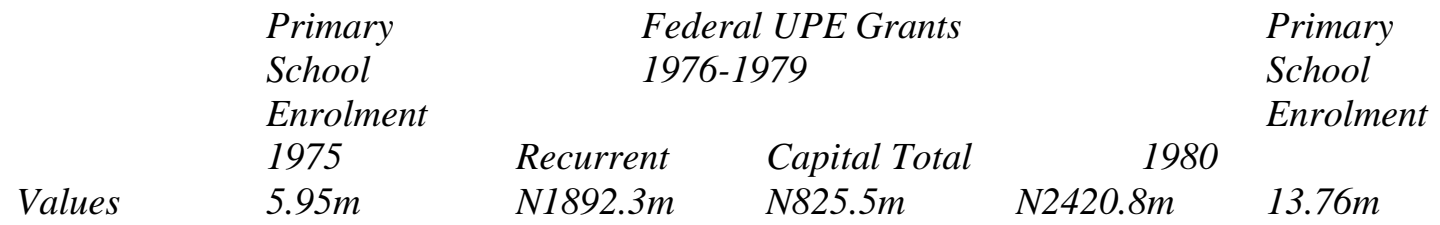

Percentage Distribution

$\begin{array}{llllll}\text { Ahambra } & 10.7 & 7.1 & 5.0 & 6.6 & 7.1 \\ \text { Bauchi } & 2.1 & 3.5 & 4.9 & 3.8 & 2.9 \\ \text { Bendel } & 10.2 & 6.8 & 5.3 & 6.5 & 6.4 \\ \text { Benue } & 4.3 & 5.0 & 4.5 & 4.9 & 6.4 \\ \text { Borno } & 2.3 & 3.7 & 5.5 & 4.1 & 2.8 \\ \text { Cross River } & 10.0 & 7.3 & 6.6 & 7.2 & 5.9 \\ \text { Gongola } & 2.7 & 3.2 & 6.9 & 4.0 & 33.5 \\ \text { Imo } & 12.4 & 8.0 & 4.6 & 7.3 & 8.6 \\ \text { Kaduna } & 3.7 & 6.3 & 7.0 & 6.4 & 7.4 \\ \text { Kano } & 2.7 & 6.7 & 9.6 & 7.3 & 7.5 \\ \text { Kwara } & 3.0 & 3.6 & 5.0 & 3.9 & 5.4 \\ \text { Lagos } & 6.0 & 3.9 & 4.9 & 4.1 & 3.8 \\ \text { Niger } & 0.9 & 2.7 & 3.6 & 2.9 & 3.0 \\ \text { Ogun } & 4.0 & 3.2 & 2.7 & 3.1 & 2.6 \\ \text { Ondo } & 5.6 & 5.3 & 3.4 & 4,9 & 4.6 \\ \text { Oyo } & 9.8 & 8.4 & 4.7 & 7.6 & 10.6 \\ \text { Plateau } & 2.5 & 4.3 & 4.9 & 4.5 & 3.8 \\ \text { Rivers } & 4.6 & 5.1 & 3.8 & 4.8 & 3.6 \\ \text { Sokoto } & 2.3 & 5.9 & 7.5 & 6.2 & 4.1\end{array}$

Source: FOS Social Statistics in Nigeria 1980 Lagos 1982.

Another power which the Federal Government holds over states is the power to authorise, guarantee or grant loans. States have made extensive use of Development Stocks and Treasury Advances to bail themselves out of financial trouble. A tradition has developed whereby every state gets something "reasonable". The practice is however different for external loans, where a few more favoured or more adventurous states succeed in concerning most of the funds available (Table 3). 
Governmental Structure, Spatial Administrative Reforms and National Development

TABLE 3

\section{PUBLIC DEBT OF STATE GOVERNMENT AS AT 31 DECEMBER 1982}

\begin{tabular}{llll} 
& \multicolumn{3}{l}{ Unfunded External Development Loan- Treasury } \\
& Loans On-lent to & Stock On lent to & Advances to \\
& States & States & States \\
Amount $N(M)$ & 112.4 & 2714.8 & 4760.7 \\
Distribution \% & 0.7 & 5.7 & 4.2 \\
Anambra & 7.5 & 4.8 & 5.2 \\
Bauchi & 7.5 & 4.8 & 5.2 \\
Bendel & 3.5 & 5.0 & 3.5 \\
Benue & 7.8 & 4.8 & 5.4 \\
Crots River & 3.9 & 5.8 & 6.5 \\
Gongola & 0.6 & 5.0 & 5.7 \\
Imo & 0.9 & 5.7 & 8.0 \\
Kaduna & 14.3 & 6.3 & 6.8 \\
Kano & 0.9 & 7.5 & 6.1 \\
Kwara & 1.1 & 4.5 & 4.2 \\
Lagos & & 4.3 & 4.2 \\
Niger & 0.3 & 3.9 & 4.6 \\
Ogun & 7.7 & 4.1 & 3.6 \\
Ondo & 10.9 & 5.0 & 4.1 \\
Oyo & 13.3 & 6.9 & 5.1 \\
Plateau & 10.5 & 4.5 & 4.5 \\
Rivers & 6.0 & 4.4 & 5.5 \\
Sokoto & 8.9 & 6.5 & 6.3
\end{tabular}

Source: Federal Republic of Nigeria Official Gazette No- 17 Vol. 72, 28 March 1985

\section{Direct Federal Government Operations}

The Federal Government operates over the entire territorial space of Nigeria. It underscores the fact that every domestic federal project is of particular interest to some state or local government as an actual or potential location. The location of federal projects is a major contributor to the overall patterns of regional development Many factors determine decisions on location. Apart from policy considerations, political and economic, there are such factors as the state of relations between the federal and state governments, the level and intensity of communication; as well as in levels of cooperation and conflict 
The Federal Government is constrained in its spatial programming by reason both of its internal structure and organisation and of the nature of its projects and operations. The federal machinery is programmed to approach matters generally and globally rather than in specific, localised detail It prefers a few large decisions to many small ones, huge, lumpy concentrated investments rather than small unbundled and dispersed projects.

The nature of the federal public service establishment itself indicates some reasons for this. Owing to its limited vision of the role of government the colonial administration did not require a large civil service. In 1957 the staff strength of the entire federal civil service was 45000 (DL 1960). Although the size and scope of government activity has greatly increased, the development of the federal civil service has not kept pace. Thus in the 21 years between 1957 and 1978, while size of the federal annual expenditure budget rose 645 times from N77.4 million to P\&992.3 million, the number of federal civil servants increased only 4 times to 184000 (FUME 1980). Furthermore, as Table 5 shows, some $41 \%$ of the federal service staff are concentrated in Lagos, and the federal staff presence in some states is faint indeed.

The tendency to concentration pervades all aspects of federal operations, both between sectors and within them. Thus the value of federal projects executed from 1979 to 1982 is summarised by executive agency (Table 4). The three leading agencies together accounted for $50.8 \%$ of total project expenditure, the first eight for $82.0 \%$. Details are given below.

\section{TABLE 4 \\ FEDERAL PROJECTS BY AGENCIES}

$\begin{array}{lcc}\text { Agency } & \begin{array}{c}\text { Percentage } \\ \text { Share }\end{array} & \begin{array}{c}\text { Cumulative } \\ \text { Percentage Share }\end{array} \\ \text { NNPC } & & \\ \text { Works } & 22.4 & 22.4 \\ \text { Steel Development } & 18.4 & 40.8 \\ \text { Communications } & 10.0 & \text { SO.O } \\ \text { Education } & 8.3 & 59.1 \\ \text { Water Resources } & 7.8 & 66.9 \\ \text { Industries } & 7.4 & 74.3 \\ \text { Health } & 4.6 & 78.9 \\ & 3.1 & 82.0\end{array}$

Within sectors the same picture of concentration is revealed. A study of implementation patterns of the 1975-80 plan indicated that the six leading projects out of 72 projects in the agricultural sector accounted for $77.5 \%$ of actual sectoral expenditure, while the six leading industrial projects to6/k 81\% of sectoral expenditure/ (Ukwu 1980). 
Governmental Structure, Spatial Administrative Reforms and National Development

TABLE 5

DIMENSIONS OF THE FEDERAL PRESENCE (PERCENTAGES)

\begin{tabular}{|c|c|c|c|c|c|c|}
\hline \multirow[t]{3}{*}{ Sate } & \multirow[t]{3}{*}{$\begin{array}{l}\text { Federal Civil } \\
\text { Services Staff } \\
\text { Disposition } \\
1980^{(1)}\end{array}$} & \multicolumn{2}{|c|}{$\begin{array}{l}\text { Federal Government } \\
\text { Projects and Financial } \\
\text { Disbursements Oct. } \\
1979 \text { to Dec. } 1983^{(2)}\end{array}$} & \multicolumn{2}{|c|}{$\begin{array}{l}\text { NIDB } \\
\text { Sanctions } \\
1973^{(3)}\end{array}$} & $\begin{array}{l}\text { Agricultural } \\
\text { Credit } \\
\text { Guarantee }\end{array}$ \\
\hline & & \multirow{2}{*}{$\begin{array}{l}\text { Total } \\
\text { Expenditure }\end{array}$} & \multirow{2}{*}{$\begin{array}{l}\text { Financial } \\
\text { Disburse- } \\
\text { Ments }\end{array}$} & \multirow{2}{*}{\multicolumn{2}{|c|}{$\begin{array}{l}\text { Projects } \\
\text { Executed }\end{array}$}} & \multirow{2}{*}{$\begin{array}{l}\text { Fund Loans } \\
1981^{(4)}\end{array}$} \\
\hline & & & & & & \\
\hline Anambra & 5.0 & 4.7 & 4.8 & 4.7 & 5.0 & 5.4 \\
\hline Bauchi & 2.2 & 3.2 & 4.2 & 2.1 & 7.4 & 8.2 \\
\hline Bendel & 4.2 & 11.0 & 6.7 & 16.0 & 4.9 & 4.6 \\
\hline Benue & 2.8 & 3.3 & 4.2 & 2.3 & 3.8 & 1.4 \\
\hline Borno & 2.3 & 3.8 & 4.6 & 2.8 & 2.1 & 0.3 \\
\hline Cross River & 4.2 & 7.0 & 4.8 & 9.6 & 6.6 & 3.5 \\
\hline Gongola & 2.4 & 4.1 & 4.3 & 3.8 & 2.5 & 10.0 \\
\hline Imo & 3.5 & 5.2 & 5.3 & 5.1 & 4.3 & 3.4 \\
\hline Kaduna & 5.9 & 5.8 & 5.3 & 6.5 & 5.6 & 8.5 \\
\hline Kano & 4.1 & 4.9 & 6.4 & 3.1 & 3.6 & 5.9 \\
\hline Kwara & 3.7 & 6.2 & 3.5 & 9.1 & 2.9 & 2.9 \\
\hline Lagos & 40.5 & 4.7 & 3.5 & 6.0 & 21.1 & 11.2 \\
\hline Niger & 1.9 & 3.8 & 5.6 & 1.7 & 3.2 & 2.2 \\
\hline Ogun & 2.3 & 3.4 & 3.3 & 3.5 & 12.7 & 9.7 \\
\hline Ondo & 1.9 & 3.6 & 4.2 & 2.9 & 0.7 & 1.8 \\
\hline Oyo & 3.9 & 7.4 & 10.0 & 4.4 & 8.2 & 7.9 \\
\hline Plateau & 3.5 & 3.4 & 3.8 & 3.0 & 0.1 & 3.4 \\
\hline Rivers & 3.5 & 4.7 & 5.7 & 3.6 & 3.4 & 3.4 \\
\hline Sokoto & 2.4 & 2.4 & 3.8 & 0.8 & -- & -- \\
\hline F.C.T. & NA & 2.4 & 3.8 & 0.8 & -- & -- \\
\hline Sokoto & 2.4 & 4.7 & 5.7 & 3.6 & 4.4 & 3.4 \\
\hline
\end{tabular}

Sources:

(1) Federal Office of Statistics- Digest of Statistics Vol. 28. June 1981

(2) Federal Government Projects and Financial Disbursements in the States, October 1979December 1982 and statutory allocations to State and Local Governments up to 31 December 1983. Federal Government Printer 1983.

(3) Business Times June 3. 1980

(4) Agricultural Credit Guarantee Scheme Fund Annual Report 1981 
TABLE 6

\section{VALUE OF FEDERAL GOVERNMENT PROJECTS IN THE STATES, OCTOBER 1979-DECEMBER BY SECTOR/EXECUTIVE AGENCY}

$\begin{array}{lll}\text { Sector/Executive Agency } & \text { Value of Projects } & \\ & \text { NM } & \% \\ \text { Agriculture } & & \\ \text { Water Resources } & 332.1 & 2.2 \\ \text { Industries } & 1097.7 & 7.4 \\ \text { Steel Development } & 675.3 & 4.6 \\ \text { Mines and Power } & 1478.9 & 10.0 \\ \text { N N P C } & 805.3 & 5.4 \\ \text { Commerce } & 3321.4 & 22.4 \\ \text { Transport } & 19.2 & 0.13 \\ \text { Aviation } & 400.9 & 2.7 \\ \text { Communication } & 210.7 & 1.4 \\ \text { Education } & 1237.6 & 8.3 \\ \text { Manpower Development } & 1159.6 & 7.8 \\ \text { Employment, Labour \& Productivity } & 0.6 & -- \\ \text { Science and Technology } & 5.0 & 0.03 \\ \text { Health } & 120.5 & 0.81 \\ \text { Social Development, Youth and Culture } & 466.2 & 3.1 \\ \text { Housing and Environment } & 7.8 & 0.05 \\ \text { Works } & 309.2 & 2.1 \\ \text { Defence } & 2726.0 & 18.4 \\ \text { Police } & 268.1 & 1.8 \\ \text { External Affairs } & 61.9 & 0.4 \\ \text { Information } & 7.1 & 0.05 \\ \text { Internal Affairs } & 80.2 & 0.54 \\ \text { National Planning } & 37.7 & 0.25 \\ \text { Total } & 0.4 & -- \\ & 14829.4 & \end{array}$

Source: Federal Government Project and Financial Disbursements in the States, October 1979December 1982 and statutory allocations to State and Local Government up to 31. 
Sectoral programmes also tend to be concentrated in a few states. Thus for the $1979-82$ period Kwara and Bendel States alone accounted for $61.9 \%$ of the project expenditure in Industry and Steel Development, while five least-favoured states - Imo, Kano, Ondo, Niger and Bauchi - together has less than $1 \%$. In the mining and petroleum sectors Bendel and Rivers states took $46.5 \%$ of the expenditure while the six least favoured states - Sokoto, Benue, Borno, Kano, Ogun and Gongola — shared 3.6\%.

The establishment of objective, testable and measurable criteria for the selection and location of federal projects, and a more rational and sustained approach to implementation would contribute effectively to integrated and even development;

\section{The Inequality of States}

Differences in resource endowment, policy orientation arid development priorities are major factors in creating inter-state differentiation in levels and patterns of development. This is particularly so because it is the states that have the primary responsibility for the sectors of the economy which most directly affect the daily lives of the people and the quality of the environment.

Differences in state revenues and expenditures indicate the patterns of inter-state inequality of resource endowment. Table 7 demonstrates the bulk of state revenues coming from federal sources.

An examination of the state budgets for one particular year, 1978, reveals how differently various states rated four major sectors - agriculture, education, health, and works and housing - in terms of budgetary appropriations (Table 8). Thus, relative to the overall inter-sectoral distribution of votes, Gongola, Benue, Plateau, and Lagos states invested highly in agriculture. Lagos, Bendel, Bauchi and Benue paid the most attention to health while one state, Niger, stood out in its involvement in works and housing. On the other hand, agriculture was relatively neglected by Rivers state, education by Ondo state, health by Kano and Ogun, works and housing by Anambra, Benue, Cross River and Kano.

Over the plan periods the differences are even more marked and more significant Thus the four Northern States have tended to emphasise investment in agriculture while neglecting education. On the other hand the Southern States have consistently devoted a high proportion of their resource* to education, while some of them have paid particular attention to industries. As illustrated earlier in the case of education, a shift in sectoral

priorities can significantly change the level of sectoral development over a long period the cumulative impact of state policies is very great. 
TABLE 7

\section{THE FINANCIAL INEQUALITY OF STATES}

Sate

\begin{tabular}{|c|c|c|c|}
\hline $\begin{array}{l}\text { Actual State } \\
\text { Capital Expen- } \\
\text { Diture } 1975\end{array}$ & $\begin{array}{l}\text { Total } \\
\text { Revenue\% }\end{array}$ & $\begin{array}{l}\text { State Revenue } \\
\text { Internal } \\
\text { Revenue \% }\end{array}$ & $\begin{array}{l}\text { Relative Internal } \\
\text { Effort Coverage } \\
=100\end{array}$ \\
\hline
\end{tabular}

Anambra $\quad 4.0$

Bauchi $\quad 4.2$

Bendel $\quad 7.4$

Benue $\quad 5.1$

Borno $\quad 4.9$

Cross River 4.8

Gongola $\quad 4.3$

Imo $\quad 5.5$

Kaduna $\quad 5.1$

Kano $\quad 6.4$

Kwara

6.4

Lagos

6.3

Niger

6.9

Ogun

3.4

Ondo

4.4

Oyo

5.8

Plateau

5.0

Rivers

4.0

Sokoto

7.4

6.3

3.0

8.4

3.4

3.9

4.7

3.5

4.9

4.4

6.6

3.2

10.4

2.5

4.5

6.0

866

3.2

5.9

7.4

118

1.1

35

10.6

1125

1.7

51

2.4

62

3.7

79

1.9

56

5.4

110

5.3

121

$5.5 \quad 82$

2.7

19.8

86

191

1.5

60

6.1

135

4.0

66

F.C.T.

1.7

11.2

130

2.2

69

4.6

78

0.3

35

Source: Ukwu I. Ukwu "Infrastructure and Regional Development" Commissioned Paper presented at the 1985 Annual Conference of the Nigerian Economic Society. 
Governmental Structure, Spatial Administrative Reforms and National Development

TABLE 8

CONTRASTING STATE PRIORITIES IN SECTORAL DEVELOPMENT 1978/79

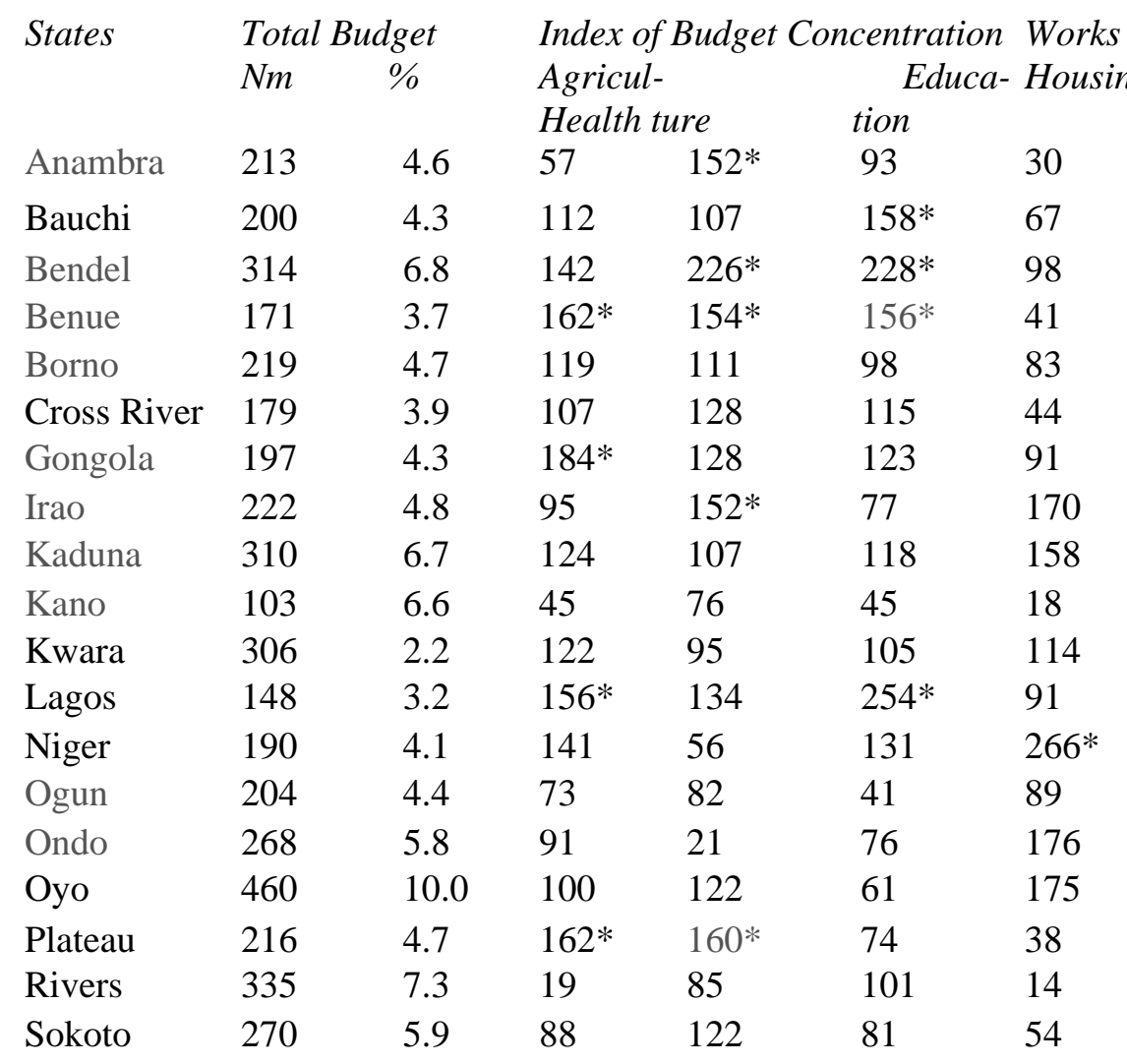

(Based on budget figures published in Current Newspapers).

Note: The base of the Index is the average share of the sector in the total allocations for all states. The state sectoral share is $(\mathrm{xi})$. Index $=(\mathrm{xi} 100)$

Sectors of low priority underlined

$\mathrm{X}$

Sectors of high priority astericised.

Local Government and Local Development ${ }^{3}$

Local Government is the most basic level of government, the level most intimately involved with the individual's immediate environment and community and which deals directly with local needs and concerns. The large variety of local circumstances supports the case for a wide diversity of objec-

3. This section draws extensively from the Kuru study of Local Government and Local Development (Ukwu etal , 1982) 


\section{Annals of the Social Science Council of Nigeria}

tives, types and instruments of local government But this consideration must be reconciled with, or, if necessary, subordinated to, the purposes, structures and usages of the higher levels of community and government.

The present-day system of local government in Nigeria has evolved from the system originally introduced by the British colonial government As we have seen under Indirect Rule, administrative order was imposed by organizing the myriads of units into a hierarchy of districts, divisions and provinces through which colonial administrative officers advised, supervised and controlled the "native authorities". But these local governments depended on their local initiative, personnel and resources for whatever social and economic development was achieved in their localities. As if to underline the dualism of development, the colonial enclaves of the new mining, transportation, commercial and administrative centres were generally administered as "townships" outside the jurisdiction of the "native authorities".

Constitutional developments after World War II formalised the federal structure of the country and interposed regional governments between the centre and the local governments, but the main features of the local government system developed under colonial rule survived into Independence and the First Republic.

A look at the situation in 1964 illustrates the main features. Each region maintained a multi-tier structure of local governments, the main authority lying with 309 principal units: 76 native authorities in the Northern Region, 125 District Councils in the Western and Midwestern Regions, and 108 Country Councils in the Eastern Region. In the Northern Region, there was very marked contrast in size, structure and functions between the largest native authorities and the smallest The great emirates of Kano, Sokoto, Zaria, Katsina, Bauchi, Borno, Adamawa and Ilorin constituted native authorities in their own right. Each held sway over millions of subjects and could muster the grandeur and resources of a state. They were able to provide a wide range of services, from education, health and other social services to agriculture and public works, at a level which made their operations more important to their localities than anything the regional government could provide. The small native authorities, located mostly in the middle Belt, consisted of fragile federations of petty chieftaincies and clans with a few thousand inhabitants. Many did not generate enough to need their own treasuries and could barely pay the salaries of their meagre staff. In the Western Region, while some of the districts were co-extensive with the larger traditional kingdoms, other districts represented unstable permutations of smaller kingdoms and principalities. In the Eastern Region, given the atomistic fragmentation of traditional political units, the local governments created were largely arbitrary administrative entities. They were fairly similar in size and function.

The hierarchical organisation of local government varied in structure and significance among the regions. It was most complex in the Northern Region 
where there were active district councils and village councils below the Native authorities and Provincial councils above them. In the West, many district councils delegated specialised functions and specific authority to Joint Boards. Provincial Councils existed in the East but were not as significant as they were in the North On the other hand community councils were much more important in the East, where a complete substratum of such councils covered the region.

From the inception of military rule there was a general trend towards centralization and uniformity. The Federal Military Government took over local government police and prisons, while the state government acquired the judicial functions. Each state government sought to stream-line its local government system by reorganising it into units of fairly similar size and function, and to assume greater direct control over its operations. In the Northern states new basic local government units commonly known as development areas were created Each of the larger emirates found its domain carved up into several such development areas, with the authority of the Emir relegated to headship of the Traditional Council made up of traditional rulers from his emirate The smaller emirates and native authorities were amalgamated into enlarged development areas. In the southern states the new system was generally known as development administration. The distinction between field administration and local government was abolished. Rather, administrative officers were posted as representatives of the state government to mobilize, direct and co-ordinate local development efforts. Building on an old tradition the East Central State formally instituted the local autonomous community as the basic unit of the local government system. Community councils were established to run community affairs and appoint delegates to the Divisional Council for common services.

The shift towards a prefect oral system of local government greatly eroded local government autonomy. Other institutional changes accelerated the process. Local Government staff were either absorbed into the state public service directly or brought under the jurisdiction of local government commission set up by the state. It also became common to establish parastatals for specific functions like education, health and sanitation cutting across the local jurisdiction of local governments.

The Muhammed Obasanjo Administration completed the process of standardisation and control by promulgating a uniform local government system in 1976. The decree laid down strict and elaborate guidelines on the size, structure and functions of local governments throughout the country. Under the guidelines some 300 new local governments were established. There was provision for Emirate/Traditional Councils for groups of local governments as well as for subordinate districts where desirable. But there were no special provisions for local communities. The new system was specially funded by statutory allocation from Federal revenues through the states. 


\section{Annals of the Soda! Science Council of Nigeria}

The main provisions of the local government decree were incorporated in the 1979 constitution, which listed the local government areas under each state. However, on the assumption of power the civilian governments of the states proceeded to reorganise the system as they saw fit. All but one (Rivers State) passed laws creating new local governments, so that by September 1962 the number had risen nearly $2 \frac{1}{2}$ times to 740 . This brought the states in conflict with the Federal Government which contested the right of states to take such action, thereby making it impossible for Federal and State authorities and institutions to collaborate and coordinate activities at local government level. Additionally, state governments differed in their attitudes and policies towards such issues as the relevance and status of traditional councils, the establishment and functions of subordinate units and the powers and responsibilities delegated to local governments. Other areas of diversity included the role of state ministries, the local governments and the Local Government Service Commissions in the recruitment and administration of local government staff, the management of primary education, and the use of state statutory bodies and specialised agencies for such local government functions as market development and refuse disposal. There was however one issue of unanimity. The constitutional provisions for democratic local government run by elected officials were completely ignored. Each state government hand-picked chairmen, supervisory councillors and management committees to manage the councils. Denied autonomy and integrity the local government system lost all credibility as a relevant tier of government.

With the return of military government in December 1983 the trends of divergence were abruptly halted. The new government decreed a reversal to the 'original' local government units of the 1979 Constitution. "Sole Administrators" were appointed to take charge of them by the various state governments. However, some of the changes introduced by the civilian regimes have survived and the system is now much less uniform than it was in 1976.

Consistent with the Babangida Administration's declared commitment to mobilisation and self-reliance the sole administrator system is being abolished in favour of management committees of appointed local persons. But there is genuine need for mass involvement in its operations.

\section{Concluding Remarks}

At a time when Nigeria is searching for a viable political order a number of fundamental decisions have to be made. The most basic is to develop a sense of national purpose, to articulate the goals of the Nigerian state and make a choice of the options for attaining them.

We have made a beginning in this direction by the official declaration of a commitment to a national strategy of national integration, social justice, mass mobilization and self-reliant development. 3y focusing on this issue the current national debate can lead to a fuller specification and concretization of national objectives, having done this we must take a look at the substantive issues of the political economy of Nigeria, the production relations 
and the underlying structure of power, the differential access to, control and use of national resources among the various classes and segments in the nation, with a view to seeking out the modalities for establishing a system more functional to the national purpose. Unless these steps are taken no amount of ginkering with the governmental structure will guarantee the delivery of good government.

But the issue of Government structures is important, having to do with the instruments and mechanisms for operating the state apparatus effectively for national ends. We have focused on some critical aspects of the spatial element of this structure. Our general conclusion is that, anatomically, the basic federal structure is adequte ${ }^{4}$, the problem is physiological. There is need to establish the habits, practices and procedures which facilitate cooperation and coordination among the various tiers of government. On the all-important question of financial relationships there is need for a permanent fiscal commission or such central body to monitor and regulate operations and keep the situation under review in the interest of all levels of government. The importance of the imaginative use of the resources of higher tiers of government to encourage and support desirable behaviour by lower levels - especially through the flexible use of nonstatutory transfers - has been highlighted.

The most critical yet sadly neglected area is that of local development. While the moribund local government system is now being revived, it needs to be stressed that particular attention must be paid to developing grassroots structures at the local community level as a vehicle for mass mobilization. Statutory incorporation of autonomous communities is suggested. (This should be preferably under state law- but should be registered and gazetted nationally). The aim would be to create a "legally bounded space ' (Yenusa 1983) for ordered local interaction. The mobilization of resources at this level requires the full involvement and harmonious cooperation of all tiers of government and the people themselves, and must be locally-based.

Finally, let it be re-iterated that unless the state is seen to protect, preserve and promote the interests of the broad masses of the people, there can be no viable and stable political order. An appropriate governmental structure can be made to work once this imperative is met.

4. One major qualification to this statement is on the matter of new states. Control of a state gives its controller one unit of power, access or benefit in many 'federal' competitive situations. On this basis the present structure is a manifestly unfair. Increasing the number of states would allow for adjustment of proportionality among the larger ethnic group in the number of states controlled, as well as permit the peaceful accommodation of the more embattled separatists in the 'minority' states. 
Annals of the Social Science Council of Nigeria

\section{BIBLIOGRAPHY}

Agricultural Credit Guarantee Scheme Fund (1981) Annual Report.

Ajayi, J.F.A and Crowder, M. (ed) 1971) History of West Africa Volume one Longman

Birch, A.H. (1970) "Inter-governmental Financial Relations in New Federations" in Taylor 1970. DL (1960) Department of Labour: Annual Report of the Department of Labour for the Year 1957-58 Lagos 1960.

Federal Republic of Nigeria (1983) Federal Government Projects and Disbursements in the States Lagos, Federal Government Printer

Federal Republic of Nigeria 91985) Official Gazette No. 17 Vol. 7228 March, 1985.

FME (1980) Federal Ministry of Establishments Federal Civil Service Manpower Statistics Lagos. 1980 FOS (1981) Federal Office of Statistics Digest of Statistics Vol. 28 June 1981.

FOS Federal Office of Statistics (1982) Social Statistics'in Nigeria 1980 Lagos 1982.

Hardy, H.M. (1976) "Budgetary Responses of Individual Government Units to Federal Grants" Public Finance Quarterly, Vol. 4 No. 2 pp. 173 - 188.

Horton, Robin (1971) "Stateless Societies in the History of West Africa" in Ajayi and Crowder 1971

N'icolson, I. F. (1969) The Administration of Nigeria: 1900-1960 London, Clarendon

Nwosu, E.J. (ed) (1985) Achieving Even Development in Nigeria: Problem and Prospects Enugu,

Fourth Dimension

Okafor. S. O. (1981) Indirect Rule: the Development of the Central Legislature in Nigeria Watton-on-

Thames, Nelson

Okigbo, P.N.C. et al (1980) Report of the Presidential Commission on Revenue Allocation Lagos. Perham. M. (193 7) Native Administration in Nigeria Oxford, Clarendon

Philips, A. (1971) "Nigeria's Federal Finance Experience" Journal of Modern African Studies. Vol 9

No. 2 pp. $389-408$.

Taylor, M.C. (ed) (1970) Taxation for African Economic Development London, Hutchison

Ukwu, U.I. (1980) "Federal Financing of Projects for National Development and Integration "National Seminar on Federal Character and National Integration Kuru, National Institute for Policy and Strategic Studies, (Now in press, Ukwu, U.I. (ed).

Ukwu, U.I. (1985a) Managing National Development Enugu, Institute for Development Studies

Ukwu, U.I. (1985b) "Even Development in Nigeria" An Overview" in Nwosu 1985: 15-58.

Ukwu, U.I. (1985c) "Infrastructure and Regional Development" Commissioned Paper presented at the 1985 Annual Conference of the Nigerian Economic Society.

Ukwu, U.I., S. O. Nwaocha, C. and Mailafiya, O. (1982) Local Government and Local Development (Policy Review Series No. 3 Kuru National Institute for Policy and Strategic Studies.

Yenusa, M. (1983) "The Grassroot Development Planning Process: the Role of Physical Planning in the Rural Environment"Planning Outlook Vol. 20 No. 2 pp 79 - 82. 